\title{
The Effect of Product Prices and Promotions on Purchasing Decisions of Mitsubishi Brand Cars at PT. Srikandi Diamond Motors, Tangerang Branch
}

\author{
Ahmad Nurhadi \\ Universitas Pamulang \\ E-mail: dosen01023@unpam.ac.id \\ (Received: December-2017; Reviewed: January-2018; Accepted: February-2018; \\ Avalaibel Online: February-2018; Published: March-2018) \\ (7) (8) This is an open access article distributed under the Creative Commons Attribution License \\ CC-BY-NC-4.0 @2018 by author (https://creativecommons.org/licenses/by-nc/4.0/)
}

\begin{abstract}
This study aims to determine the effect of product prices and promotions on purchasing decisions of Mitsubishi brand cars at PT. Srikandi Diamond Motors Tangerang Branch. The method used was explanatory research with a sample of 96 respondents. The analysis technique uses statistical analysis with regression testing, correlation, determination and hypothesis testing. The results of this study the price of products significantly influence the decision to purchase a Mitsubishi brand car by $42.7 \%$, the hypothesis test obtained significance of $0,000<0.05$. Promotion has a significant effect on the decision to purchase a Mitsubishi brand car of $43.1 \%$, the hypothesis test obtained a significance of $0,000<0.05$. Product prices and promotions simultaneously have a significant effect on purchasing decisions of Mitsubishi brand cars by $53.5 \%$, hypothesis testing obtained significance of $0,000<0.05$.
\end{abstract}

Keywords: Product price; promotion; decision to purchase Mitsubishi brand cars.

\section{INTRODUCTION}

In the current era of globalization, competition in the automotive industry is very tight, as evidenced by the number of car brands that exist on the highway in the Tangerang area in particular (Astuti \& Lestari, 2019; Jati, 2019; Rozi, 2020; Suyatin, 2019). With so many brands that exist, making the company try to how to be superior to its competitors. This condition causes motor vehicle companies to compete with each other by making their vehicles superior to other vehicles whose aim is to fight over customers. Because customers at this time tend to be more critical and they have many choices to choose a car that suits their expectations (Kencana, 2018; Wicaksono, 2019).

The car is a very important means of transportation used by humans to deliver people or goods from one place to another (Gundlach et al., 2018; Naganathan \& Chong, 2017; Nurhadi et al., 2017; Paloheimo et al., 2016; Sun et al., 2018). That requires a car with a powerful engine, a good model, an affordable price so that the car is in demand in the market (Cravens, 1996). 
Aside from being a means of transportation, the car is now also functioning as a symbol of social status, and as a complement to the appearance or fashion of its owner. Therefore, it is a necessity for car manufacturers to make car products that have at least three of the above functions (Kencana, 2018).

All manufacturers are currently competing to offer products by offering a variety of attractions embedded in the cars they sell. Each manufacturer and distributor competed in delivering ownership of the attraction of their respective cars. Companies must be able to recognize what the needs and expectations of consumers, because consumers in buying products have gone through a process or stages first before buying a product. Consumer behavior is a very important phenomenon in corporate marketing activities, namely consumer behavior in making purchases (Irawan, 2011).

PT.Srikandi Diamond Motors is a Mitsubishi passanger car sales showroom. The company is trying to increase its car sales every year and is more concerned with growing interest in purchasing, therefore PT. Srikandi Diamond Motors has 3S Sales facilities (can help consumers in the field of sales), Service (helps consumers in the field of regular maintenance of the vehicle) and Spare Parts (meet the needs of spare parts if there is damage that must be replaced), so that what is needed by consumers is the main attraction convince consumers to buy a vehicle with adequate facilities (Sunarsi \& Baharuddin, 2019; Yuangga \& Susanti, 2019; Zulkifli et al., 2018).

In purchasing a vehicle many things affect consumers, one of which is price. Price according to Keller \& Lane (2013) is the amount of money exchanged for a product or service. The price is also the thing that is most considered by consumers when purchasing a product so the company must be careful in pricing and not only the price that must be considered will be fixed, the price also affects the quality of the goods. So the quality of the will have a quality price too.

Advertising is one of the sub variables of promotion which is a concept in modern marketing theory (Jumiani et al., 2018; Kencana, 2018; Zulkifli et al., 2018). Advertising can be said as one of the determinants of the development and growth of a company. The process of recognition with a continuous frequency of time is very effective for later consumed by the market. The process can naturally instill assumptions that are taken into consideration before the purchase decision process and if the car industry wants to remain exisis in the automotive world, it must be consistent with the strategy (Astuti \& Amalah, 2020; Kurniawati et al., 2019; Suyatin, 2019; Syatoto, 2020).

Like the Mitsubishi brand car, besides being seen as a means of mass transportation as well as a private car that is needed by the people of Indonesia. Motivation of ownership and purchase is based on economic value and needs that must exist as a means of transportation in work, recreation and so on. Even at this time many families have more car brands all brands of four-wheeled vehicles or cars competing to create new innovation models, designs continue to be tested and developed according to the tastes of consumers PT. Srikandi Diamond Motors also faces challenges in the field of marketing between showrooms. For that reason, management of Srikandi Diamond Motors knows what factors influence consumer purchasing decisions in order to formulate an appropriate marketing strategy in marketing Mitsubishi brand cars.

Based on the description in the background above, the authors are interested in researching with the title: Effect of product prices and product promotions on purchasing decisions of Mitsubishi brand cars at PT. Srikandi Diamond Motors Tangerang City Alam Sutera Branch. 


\section{METHOD}

The type of research used is associative. The population in this study amounted to 96 respondents PT. Srikandi Diamond Motors Tangerang Branch. The sampling technique in this study is saturated sampling, where all members of the population are sampled. Thus the sample in this study amounted to 96 respondents. In analyzing the data used the instrument test, classical assumption test, regression, coefficient of determination and hypothesis testing.

\section{RESULT AND DISCUSSION}

\section{Result}

\section{Descriptive Analysis}

In this test used to determine the minimum and maximum scores, mean scores and standard deviations of each variable. The results are as follows:

Table 1.

Results of Descriptive Statistics Analysis

\section{Descriptive Statistics}

\begin{tabular}{l|r|r|r|r|r}
\hline & N & Minimum & Maximum & $\begin{array}{c}\text { The } \\
\text { mean }\end{array}$ & $\begin{array}{c}\text { Std. } \\
\text { Deviation }\end{array}$ \\
\hline Product Price (X1) & 96 & 32 & 48 & 38.49 & 3,847 \\
\hline Promotion (X2) & 96 & 30 & 45 & 38.42 & 3,661 \\
\hline Purchase Decision (Y) & 96 & 32 & 46 & 39.16 & 3,573 \\
\hline Valid N (listwise) & 96 & & & & \\
\hline
\end{tabular}

The product price obtained a minimum variance of 32 and a maximum variance of 48 with a mean score of 3.85 with a standard deviation of 3.847. Promotion obtained a minimum variance of 30 and a maximum variance of 45 with a mean score of 3.84 with a standard deviation of 3.661. The purchase decision obtained a minimum variance of 32 and a maximum variance of 46 with a mean score of 3.92 with a standard deviation of 3.573 .

\section{Verification Analysis}

This analysis is intended to determine the effect of independent variables on the dependent variable. The test results are as follows:

\section{a. Multiple Linear Regression Analysis}

This regression test is intended to determine changes in the dependent variable if the independent variable changes. The test results are presented in table 2. 
Table 2.

Results of Multiple Liner Regression Testing

Coefficients a

\begin{tabular}{|c|c|c|c|c|c|}
\hline \multirow[b]{2}{*}{ Model } & \multicolumn{2}{|c|}{$\begin{array}{l}\text { Unstandardized } \\
\text { Coefficients }\end{array}$} & \multirow{2}{*}{$\begin{array}{c}\text { Standardized } \\
\text { Coefficients } \\
\text { Beta }\end{array}$} & \multirow[b]{2}{*}{$\mathrm{t}$} & \multirow[b]{2}{*}{ Sig. } \\
\hline & $\mathrm{B}$ & $\begin{array}{l}\text { Std. } \\
\text { Error }\end{array}$ & & & \\
\hline $1 \quad$ (Constant) & 9,228 & 2,905 & & 3,177 & .002 \\
\hline Product Price (X1) & .376 & .082 & .405 & 4,571 & .000 \\
\hline Promotion (X2) & .402 & .087 & .412 & 4,648 & .000 \\
\hline
\end{tabular}

a. Dependent Variable: Purchase Decision (Y)

Based on the test results in the above table, the regression equation $\mathrm{Y}=9,228+0,376 \mathrm{X} 1+$ $0,402 \mathrm{X} 2$ is obtained. From the equation explained as follows:

1) A constant of 9,228 means that if there is no product price and promotion, then there is a decision value for purchasing a Mitsubishi brand car of 9,228 points.

2) Product price regression coefficient of 0.376 , this number is positive, meaning that every time there is an increase in product price of 0.376 , the decision to purchase a Mitsubishi brand car will also increase by 0.376 points.

3) Promotional regression coefficient of 0.402 , this number is positive, meaning that every time there is an increase in promotion of 0.402 , the decision to purchase a Mitsubishi brand car will also increase by 0.402 points.

\section{b. Correlation Coefficient Analysis}

Correlation coefficient analysis is intended to determine the degree of relationship strength of the independent variables on the dependent variable either partially or simultaneously. The test results are as follows:

Table 3.

Results of Testing the Correlation Coefficient of Product Prices on Purchasing Decisions.

\section{Correlations}

\begin{tabular}{llr|r}
\hline & & Product Price (X1) & \multicolumn{1}{c}{ Purchase Decision (Y) } \\
\hline Product Price (X1) & $\begin{array}{l}\text { Pearson } \\
\text { Correlation }\end{array}$ & 1 & $.654^{* *}$ \\
\cline { 2 - 4 } & Sig. (2-tailed) & & .000 \\
\hline Purchase Decision (Y) & $\begin{array}{l}\text { Pearson } \\
\text { Correlation }\end{array}$ & $.654^{* *}$ & 1 \\
\cline { 2 - 4 } & Sig. (2-tailed) & .000 & \\
\hline
\end{tabular}

**. Correlation is significant at the 0.01 level (2-tailed).

b. Listwise $\mathrm{N}=96$

Based on the test results obtained a correlation value of 0.654 means that the price of the product has a strong relationship with the decision to purchase a Mitsubishi brand car. 
Table 4.

Results of Testing the Correlation Coefficient Promotion of Purchasing Decisions.

\section{Correlations ${ }^{b}$}

\begin{tabular}{|c|c|c|c|}
\hline & & Promotion $(\mathrm{X} 2)$ & Purchase Decision $(\mathrm{Y})$ \\
\hline \multirow[t]{2}{*}{ Promotion (X2) } & Pearson Correlation & 1 & .656 \\
\hline & Sig. (2-tailed) & & .000 \\
\hline \multirow[t]{2}{*}{ Purchase Decision $(\mathrm{Y})$} & Pearson Correlation & $.656^{* *}$ & 1 \\
\hline & Sig. (2-tailed) & .000 & \\
\hline
\end{tabular}

**. Correlation is significant at the 0.01 level (2-tailed).

b. Listwise $\mathrm{N}=96$

Based on the test results obtained a correlation value of 0.656 means that promotion has a strong relationship with the Purchasing decision.

Table 5.

Simultaneous Coefficient Test Results for Product Prices and Promotions on Purchasing Decisions

\section{Summary Model}

\begin{tabular}{lr|r|r|r}
\hline Model & R & R Square & Adjusted R Square & Std. Error of the Estimate \\
\hline 1 & $.732^{\mathrm{a}}$ & .535 & .525 & 2,461 \\
\hline
\end{tabular}

a. Predictors: (Constant), Promotion (X2), Product Price (X1)

Based on the test results obtained a correlation value of 0.732 means that the price of products and promotions simultaneously have a strong relationship to the decision of purchasing a Mitsubishi brand car.

\section{c. Analysis of the Coefficient of Determination}

Analysis of the coefficient of determination is intended to determine the percentage of influence of the independent variable on the dependent variable either partially or simultaneously. The test results are as follows:

Table 6.

Test Results for the Determination Coefficient of Product Prices on Purchasing Decisions.

Summary Model

\begin{tabular}{lr|rr|r}
\hline Model & R & R Square & Adjusted R Square & Std. Error of the Estimate \\
\hline 1 & $.654{ }^{a}$ & .427 & .421 & 2,718 \\
\hline
\end{tabular}

a. Predictors: (Constant), Product Price (X1)

Based on the test results obtained a determination value of 0.427 means that the price of the product has an influence contribution of $42.7 \%$ on the decision to purchase a Mitsubishi brand car. 
Table 7.

Test Results for Promotion Determination Coefficient on Purchasing Decisions

Summary Model

\begin{tabular}{lr|r|r|r}
\hline Model & R & R Square & Adjusted R Square & Std. Error of the Estimate \\
\hline 1 & $.656^{\mathrm{a}}$ & .431 & .425 & 2,709 \\
\hline
\end{tabular}

a. Predictors: (Constant), Promotion (X2)

Based on the test results obtained a determination value of 0.431 means that the promotion has a contribution of $43.1 \%$ of the decision to purchase a Mitsubishi brand car.

Table 8.

Test Results for the Coefficient of Product Price Determination and Promotion of Purchasing Decisions

Summary Model

\begin{tabular}{lr|r|r|r}
\hline Model & R & R Square & Adjusted R Square & Std. Error of the Estimate \\
\hline 1 & $.732^{a}$ & .535 & .525 & 2,461 \\
\hline
\end{tabular}

a. Predictors: (Constant), Promotion (X2), Product Price (X1)

Based on the test results obtained a determination value of 0.535 means that the simultaneous price of the product and promotion has an influence contribution of 53.5\% on the purchase decision of a Mitsubishi brand car, while the remaining $46.5 \%$ is influenced by other factors.

\section{Hypothesis testing}

\section{a. Partial hypothesis test ( $t$ test)}

Hypothesis testing with $\mathrm{t}$ test is used to find out which partial hypotheses are accepted. First Hypothesis: There is a significant influence between product prices on purchasing decisions for Mitsubishi brand cars.

Table 9. Results of the Product Price Hypothesis Tests Against Purchasing Decisions

Coefficients a

\begin{tabular}{|c|c|c|c|c|c|}
\hline \multirow[b]{2}{*}{ Model } & \multicolumn{2}{|c|}{$\begin{array}{l}\text { Unstandardized } \\
\text { Coefficients }\end{array}$} & \multirow{2}{*}{$\begin{array}{c}\begin{array}{c}\text { Standardized } \\
\text { Coefficients }\end{array} \\
\text { Beta } \\
\end{array}$} & \multirow[b]{2}{*}{$\mathrm{t}$} & \multirow[b]{2}{*}{ Sig. } \\
\hline & $\mathrm{B}$ & Std. Error & & & \\
\hline $1 \quad$ (Constant) & 15,787 & 2,804 & & 5,631 & .000 \\
\hline Product Price $(\mathrm{X} 1)$ & 607 & .72 & .654 & 8,377 & .000 \\
\hline
\end{tabular}

a. Dependent Variable: Purchase Decision (Y)

Based on the test results in the above table, the value of $t$ count $>t$ table or $(8.333>1.661)$ is obtained, thus the first hypothesis proposed that there is a significant influence between the price of the product on the decision to purchase a Mitsubishi brand car is accepted. 
Table 10.

Results of the Promotional Hypothesis Test Against Purchasing Decisions

Coefficients a

\begin{tabular}{|c|c|c|c|c|c|c|}
\hline \multirow{2}{*}{\multicolumn{2}{|c|}{ Model }} & \multicolumn{2}{|c|}{ Unstandardized Coefficients } & \multirow{2}{*}{$\frac{\text { Standardized Coefficients }}{\text { Beta }}$} & \multirow[b]{2}{*}{$\mathrm{t}$} & \multirow[b]{2}{*}{ Sig. } \\
\hline & & B & Std. Error & & & \\
\hline \multirow[t]{2}{*}{1} & (Constant) & 14,545 & 2,930 & & 4,964 & .000 \\
\hline & Promotion (X2) & .641 & .076 & .656 & 8,437 & .000 \\
\hline
\end{tabular}

a. Dependent Variable: Purchase Decision (Y)

Based on the test results in the table above, the value of $t$ count $>t$ table or $(8.437>1.661)$ is obtained, thus the second hypothesis proposed that there is a significant influence between promotion of the decision to purchase a Mitsubishi brand car is accepted.

\section{b. Simultaneous Hypothesis Test (Test F)}

Hypothesis testing with the $\mathrm{F}$ test is used to find out which simultaneous hypotheses are accepted. The third hypothesis There is a significant influence between product prices and promotions on the decision to purchase a Mitsubishi brand car.

Table 11.

Hypothesis Test Results for Product Prices and Promotions on Purchasing Decisions.

ANOVA a

\begin{tabular}{llr|r|r|r|c}
\hline \multicolumn{1}{l}{ Model } & Sum of Squares & \multicolumn{1}{c}{ df } & Mean Square & F & Sig. \\
\hline \multirow{2}{*}{1} & Regression & 649,178 & 2 & 324,589 & 53,572 & $.0000^{\text {b }}$ \\
\cline { 2 - 7 } & Residual & 563,478 & 93 & 6,059 & \\
\cline { 2 - 7 } & Total & 1212,656 & 95 & & & \\
\hline
\end{tabular}

a. Dependent Variable: Purchase Decision (Y)

b. Predictors: (Constant), Promotion (X2), Product Price (X1)

Based on the test results in the above table, the value of $\mathrm{F}$ count> $\mathrm{F}$ table or (53.572> 2,700 ) is obtained, thus the third hypothesis proposed that there is a significant influence between product price and promotion on the purchase decision of a Mitsubishi brand car is accepted.

\section{Discussion}

\section{Effect of Product Prices on Purchasing Decisions}

Product prices have a significant effect on purchasing decisions for Mitsubishi brand cars with a correlation of 0.654 or have a strong relationship with a contribution of $42.7 \%$. Hypothesis testing obtained $\mathrm{t}$ count $>\mathrm{t}$ table or $(8.333>1.661)$. Thus the first hypothesis proposed that there is a significant effect between product prices on purchasing decisions for Mitsubishi brand cars is accepted. 


\section{Effect of Promotion on Purchasing Decisions}

Promotion has a significant effect on purchasing decisions of Mitsubishi brand cars with a correlation of 0.656 or has a strong relationship with a contribution of $43.1 \%$. Hypothesis testing obtained $t$ count $>t$ table or $(8.437>1.661)$. Thus the second hypothesis is proposed that there is a significant influence between the promotion of the purchase decision of Mitsubishi brand cars accepted.

\section{Effect of Product Prices and Promotions on Purchasing Decisions}

Product prices and promotions have a significant effect on purchasing decisions for Mitsubishi brand cars by obtaining a regression equation $\mathrm{Y}=9,228+0,376 \mathrm{X} 1+0,402 \mathrm{X} 2$, a correlation value of 0,732 or having a strong relationship with a contributing effect of $53.5 \%$ while the remaining $46.5 \%$ influenced by other factors. Hypothesis testing obtained $F$ value $>F$ table or (53.572> 2.700). Thus the third hypothesis proposed that there is a significant influence between product prices and promotions on the decision to purchase a Mitsubishi brand car is accepted.

\section{CONCLUSION}

Product prices significantly influence the decision to purchase a Mitsubishi brand car with a contribution of $42.7 \%$. Hypothesis testing obtained $t$ count $>t$ table or $(8.333>1.661)$. Promotion has a significant effect on the decision to purchase a Mitsubishi brand car with a contribution of $43.1 \%$. Hypothesis testing obtained $t$ value> $t$ table or $(8.437>1.661)$. Product prices and promotions have a significant effect on purchasing decisions for Mitsubishi brand cars with a contribution of $53.5 \%$ while the remaining $46.5 \%$ are influenced by other factors. Hypothesis testing obtained by the calculated $\mathrm{F}$ value $>\mathrm{F}$ table or $(53.572>2.700)$.

\section{REFERENCES}

Astuti, E. P., \& Amalah, N. (2020). Effect of Work Discipline on employee performance in the Office of Public Appraisal Services Herly, Ariawan and Partners. PINISI Discretion Review, 1(2), 39-46.

Astuti, E. P., \& Lestari, A. (2019). The Effect of Working Capital and Liquidity on Profitability at PT. Nippon Indosari Corpindo, Tbk in 2009-2017. PINISI Discretion Review, 3(1), 2128.

Cravens, D. W. (1996). Pemasaran strategis. Jakarta: Erlangga.

Gundlach, A., Ehrlinspiel, M., Kirsch, S., Koschker, A., \& Sagebiel, J. (2018). Investigating people's preferences for car-free city centers: A discrete choice experiment. Transportation Research Part D: Transport and Environment, 63, 677-688. https://doi.org/https://doi.org/10.1016/j.trd.2018.07.004 
Irawan, B. S. (2011). Manajemen Pemasaran Modern. In Liberty. Yogyakarta.

Jati, W. (2019). The Effect of Financial Leverage, Operating Leverage and Current Ratio on Profitability at PT. Manunggal Persada Jakarta. PINISI Discretion Review, 3(2), 135-142.

Jumiani, J., Hattab, S., \& Faisal, M. (2018). Employee Performance at the Office of Population and Civil Registration in North Morowali Regency. PINISI Discretion Review, 1(2), 103108.

Keller, K., \& Lane, K. (2013). Marketing Management. New Jersey: Prentice Hall.

Kencana, P. N. (2018). The Effect of Price and Product Quality on Customer Satisfaction. PINISI Discretion Review, 2(1), 53-60.

Kurniawati, R., Triyanti, N., \& Daraba, D. (2019). Tourism Object Development Strategy in Rejang Lebong Regency Bengkulu Province. PINISI Discretion Review, 3(2), 143-150.

Naganathan, H., \& Chong, W. K. (2017). Evaluation of state sustainable transportation performances (SSTP) using sustainable indicators. Sustainable Cities and Society, 35, 799-815. https://doi.org/https://doi.org/10.1016/j.scs.2017.06.011

Nurhadi, L., Borén, S., Ny, H., \& Larsson, T. (2017). Competitiveness and sustainability effects of cars and their business models in Swedish small town regions. Journal of Cleaner Production, 140, 333-348. https://doi.org/https://doi.org/10.1016/j.jclepro.2016.04.045

Paloheimo, H., Lettenmeier, M., \& Waris, H. (2016). Transport reduction by crowdsourced deliveries - a library case in Finland. Journal of Cleaner Production, 132, 240-251. https://doi.org/https://doi.org/10.1016/j.jclepro.2015.04.103

Rozi, A. (2020). The Influence of Promotion and Distribution Accuracy on Consumer Purchase Interest in PT. Enzym Bioteknologi Internusa. PINISI Discretion Review, 1(1), 119-126.

Sun, L., Wang, S., Liu, S., Yao, L., Luo, W., \& Shukla, A. (2018). A completive research on the feasibility and adaptation of shared transportation in mega-cities - A case study in Beijing. Applied Energy, 230, 1014-1033. https://doi.org/https://doi.org/10.1016/j.apenergy.2018.09.080

Sunarsi, D., \& Baharuddin, A. (2019). The Effect of Service Quality and Price Accuracy on Consumer Confidence and Implications for Sales Increase. PINISI Discretion Review, $3(2), 101-110$.

Suyatin, S. (2019). The Effect of Leadership Style on Employee Performance of the PPIC Division of PT. Prima Components Indonesia BSD-Tangerang. PINISI Discretion Review, $3(1), 61-68$.

Syatoto, I. (2020). The Effect of Work Discipline and Motivation on Employee Performance at PT. Pos Indonesia Pondokaren Branch. PINISI Discretion Review, 1(2), 47-54.

Wicaksono, W. (2019). Influence of Competence and Customer Service Motivation on the Performance of the Bank Syariah Mandiri Remittance Business Unit. PINISI Discretion Review, 3(1), 93-102.

Yuangga, K. D., \& Susanti, N. (2019). The Influence of Embeddedness of Socio-Economic Status and Self-Control on Consumptive Behavior of Students (at MA Khazanah 
184 Pinisi Discretion Review

Volume 3, Issue 2, March, 2020 Page, 175- 184

Kebajikan Ciputat). PINISI Discretion Review, 3(1), 103-110.

Zulkifli, Z., Suasa, S., Mukarramah, M., Daswati, D., \& Samad, M. A. (2018). Village Funds Supervision by the Village Consultative Body (BPD) in Batumatoru Village, Lariang District, Pasangkayu Regency. PINISI Discretion Review, 1(2), 109-112. 